\title{
The mycorrhizal pathway of zinc uptake contributes to zinc accumulation in barley and wheat grain
}

\author{
Antonio Coccina', Timothy R. Cavagnaro², Elisa Pellegrino', Laura Ercoli', Michael J. McLaughlin² and
} Stephanie J. Watts-Williams ${ }^{2,3^{*}}$

\begin{abstract}
Background: Increasing zinc (Zn) concentrations in crops is important for alleviation of human Zn deficiency. Arbuscular mycorrhizal fungi (AMF) contribute to plant Zn uptake, but their contribution to $\mathrm{Zn}$ in the edible portion of crops has not yet been investigated. This study aimed to quantify the mycorrhizal pathway of Zn uptake into grain of wheat and barley under varying soil Zn availabilities. Bread wheat (Triticum aestivum) and barley (Hordeum vulgare) were grown in pots with a hyphal compartment containing ${ }^{65} \mathrm{Zn}$. Plants were inoculated with Rhizophagus irregularis and grown at three soil $\mathrm{Zn}$ concentrations. Radioactive $\mathrm{Zn}$ in grain and straw was measured and the contribution of AMF to Zn uptake was calculated.

Results: The mycorrhizal pathway of Zn uptake contributed up to $24.3 \%$ of total above-ground $\mathrm{Zn}$ in wheat, and up to $12.7 \%$ of that $\mathrm{Zn}$ in barley. The greatest contribution by the mycorrhizal pathway was observed in barley at the lowest $\mathrm{Zn}$ addition, and in wheat at the highest one. In addition, grain yield of bread wheat was increased by AMF.
\end{abstract}

Conclusions: These results suggest that AMF have a substantial role in uptake of $\mathrm{Zn}$ into cereals, and the proportional contribution by the MPU is dependent on plant species, as well as available soil Zn.

Keywords: Arbuscular mycorrhizal fungi, Barley (Hordeum vulgare), Radioisotope tracing, Wheat (Triticum aestivum), Yield, Zinc nutrition

\section{Background}

Zinc (Zn) malnutrition is a major global health problem for people relying on cereal-based foods as their major source of energy and minerals [4]. It was estimated that $17.3 \%$ of the world's population is at risk of inadequate dietary $\mathrm{Zn}$ intake [51]. This problem is especially pertinent in the regions where the plant-available (rather than total) $\mathrm{Zn}$ in soils is low [6]. Consequently, finding solutions for increasing $\mathrm{Zn}$ concentrations in the edible portions of crop plants is an important hurdle to improve food quantity and quality, especially in the context of an

\footnotetext{
* Correspondence: stephanie.watts-williams@adelaide.edu.au

${ }^{2}$ The School of Agriculture, Food and Wine, and the Waite Research Institute, The University of Adelaide, PMB 1, Glen Osmond, South Australia 5064, Australia

${ }^{3}$ Australian Research Council Centre of Excellence in Plant Energy Biology,

The University of Adelaide, Glen Osmond, South Australia, Australia

Full list of author information is available at the end of the article
}

increasing global human population and a changing climate [31].

The lack of sufficient $\mathrm{Zn}$ in plants can affect the synthesis and function of a wide range of macromolecules, and decrease the yield and quality of crops as a consequence $[2,6,9,49]$. Furthermore, foods produced from Zn-deficient crops (considered to be $<15$ and $<20 \mathrm{mg}$ $\mathrm{Zn} \mathrm{kg}^{-1}$ dry mass, in grains and shoots, respectively) may result in human $\mathrm{Zn}$ deficiency, which can in turn have an impact on human wellbeing by reducing the body immune functions, and increasing the risk of growth stunting in children or the risk of adverse pregnancy outcomes in women $[2,19]$.

Plants mainly acquire $\mathrm{Zn}$ from the soil in the form of free ions $\left(\mathrm{Zn}^{2+}\right.$ and $\left.\mathrm{ZnOH}^{+}\right)$. Numerous soil edaphic factors limit $\mathrm{Zn}$ phytoavailability, including: low total $\mathrm{Zn}$ concentration, high $\mathrm{CaCO}_{3}$, high organic matter 
contents $(>3 \%)$, neutral or alkaline $\mathrm{pH}$, low redox conditions, high concentration of ligands capable of forming organo-Zn complexes, and high micronutrient or macronutrient (especially P) concentrations [2, 24, 26]. However, $\mathrm{Zn}$ can also be toxic for the plants when present in excess in soil [32]. Increasing plant acquisition of $\mathrm{Zn}$ in Zn-deficient soils has been studied previously [6, 7, 42, 43, 50]. For example, in Southeast Asia, the interdisciplinary program HarvestPlus continues to develop and release new wheat and other crop varieties that have been bred to accumulate higher grain $\mathrm{Zn}$ concentration [37].

Arbuscular mycorrhizal fungi (AMF) can form associations with the roots of about $80 \%$ of terrestrial plant species, and exchange soil-derived nutrients for plant-derived photosynthates and lipids [22, 39]. Since AMF have the ability to improve the nutrition of the host plant through increased uptake of soil mineral nutrients, their potential as natural fertilizers (biofertilizers) is increasingly recognised; this is especially relevant for the uptake of relatively immobile nutrients (e.g. $\mathrm{P}, \mathrm{Zn}, \mathrm{Fe}, \mathrm{Cu}, \mathrm{K}$ ) from the nutrient depletion zones that can form around roots [33, 34, 46]. Moreover, AMF can alleviate heavy metal toxicity in the host plants and help to tolerate to high metal concentrations in the soil [18, 27, 30, 41].

Plants colonized by AMF have two soil nutrient uptake pathways: (1) directly via the root epidermis (direct pathway of uptake; DPU), and (2) via fungal structures that form the mycorrhizal pathway of uptake (MPU) [40]. Using ${ }^{65} \mathrm{Zn}$, Jansa et al. [20] quantified the MPU contribution to plant $\mathrm{Zn}$ by the proportion of the labelled nutrient added and transported into the shoots of maize plants inoculated with the AMF Glomus intraradices (renamed to: Rhizophagus irregularis). More recently, Watts-Williams et al. [48] used ${ }^{65} \mathrm{Zn}$ to quantify the total amount of $\mathrm{Zn}$ and the relative contribution (\%) of $\mathrm{Zn}$ delivered via the MPU and DPU, respectively, in shoots of tomato plants inoculated with $R$. irregularis. In that study, the greatest amount of $\mathrm{Zn}$ delivered via the MPU to the shoots was $21.7 \mu \mathrm{g}$ at the medium $\mathrm{Zn}$ concentration treatment (DTPA-extractable $\mathrm{Zn} 9.0 \mu \mathrm{gg}^{-1}$ ), and the highest relative contribution of the MPU was up to $24.2 \%$ at the low $\mathrm{Zn}$ concentration treatment (soil DTPA-extractable $\mathrm{Zn} 1.0 \mu \mathrm{g} \mathrm{g}^{-1}$ ).

It is likely that values of contribution by AMF to plant Zn uptake are highly dependent on the host plant species, as is the case for P uptake [40]. Therefore, it is important to quantify the MPU for $\mathrm{Zn}$ in important crop species. Cereal crops represent a major source of minerals and protein in the developing world, but around the 50\% of soils where cereals are cultivated are considered Zn-deficient $[2,6]$. To our knowledge, there are no studies that have directly measured the contribution of the $\mathrm{Zn}$ MPU to the edible portion of any cereal species, thus we designed this study to test the following specific aims:
1. To quantify the contribution of the MPU to $\mathrm{Zn}$ uptake in bread wheat and barley, and in particular, to the grains;

2. To investigate whether contribution to plant $\mathrm{Zn}$ via the MPU is modified under a range of soil $\mathrm{Zn}$ concentrations;

3. To study the effects of AMF inoculation on plant yield and $\mathrm{Zn}$ concentration in bread wheat and barley.

To test these aims, we undertook a glasshouse study in which radioactively labelled $\mathrm{Zn}$ was used to quantify the MPU for two cereal crops (bread wheat and barley) at three different soil $\mathrm{Zn}$ availabilities.

\section{Results}

Arbuscular mycorrhizal fungal colonization

At physiological maturity (GS90), roots of bread wheat and barley inoculated with Rhizophagus irregularis were well colonized (mean values of 53 and 46\%, for bread wheat and barley, respectively) and the percentage of colonization was significantly affected by $\mathrm{Zn}$ application (Additional file 1: Table S1; Fig. 1). In bread wheat, mycorrhizal colonization decreased by $16 \%$ with increasing soil $\mathrm{Zn}$ concentration from Low/Medium $\mathrm{Zn}$ to High $\mathrm{Zn}$. By contrast, in barley AMF root colonization was higher at Low $\mathrm{Zn}$ and High $\mathrm{Zn}$ (mean value: $51 \%$ ) than at Medium Zn (36\%).

\section{Plant growth, yield and yield components}

For bread wheat and barley, the plant biomass, yield, and yield components were differently affected by AMF inoculation and $\mathrm{Zn}$ application (Table 1). In bread wheat, above-ground biomass (grain + straw + chaff) was greater at Medium $\mathrm{Zn}$ than at Low Zn or High Zn, and did not vary with AMF inoculation (Additional file 1: Table S2).

In bread wheat, the grain yield, chaff, number of kernels per spike, and Spike Fertility Index (SFI) were each significantly affected by AMF inoculation. Specifically, grain yield was $21 \%$ greater in the inoculated plants $(+\mathrm{M})$ than in the control plants $(-\mathrm{M})(0.99 \mathrm{~g}$ and $0.82 \mathrm{~g}$ plant $^{-1}$, respectively; Fig. 2a), and number of kernels per spike, and SFI were 23 and $73 \%$ higher in the $+M$ plants, respectively (Fig. 2e). By contrast, chaff was $28 \%$ lower in $+\mathrm{M}$ than in $-\mathrm{M}$ plants (Additional file 1: Table S2). Straw biomass (Fig. 2c) and mean kernel weight (MKW; Fig. 2g) were not affected by AMF inoculation, but were modified by $\mathrm{Zn}$ application, with values decreasing by 8 and 3\%, respectively, from Low/Medium Zn to High Zn.

In barley, neither AMF inoculation nor Zn application affected above ground biomass, grain yield, straw, chaff or SFI (Table 1; Fig. 2b,d; Additional file 1: Table S3). Among yield components, number of kernels per spike 


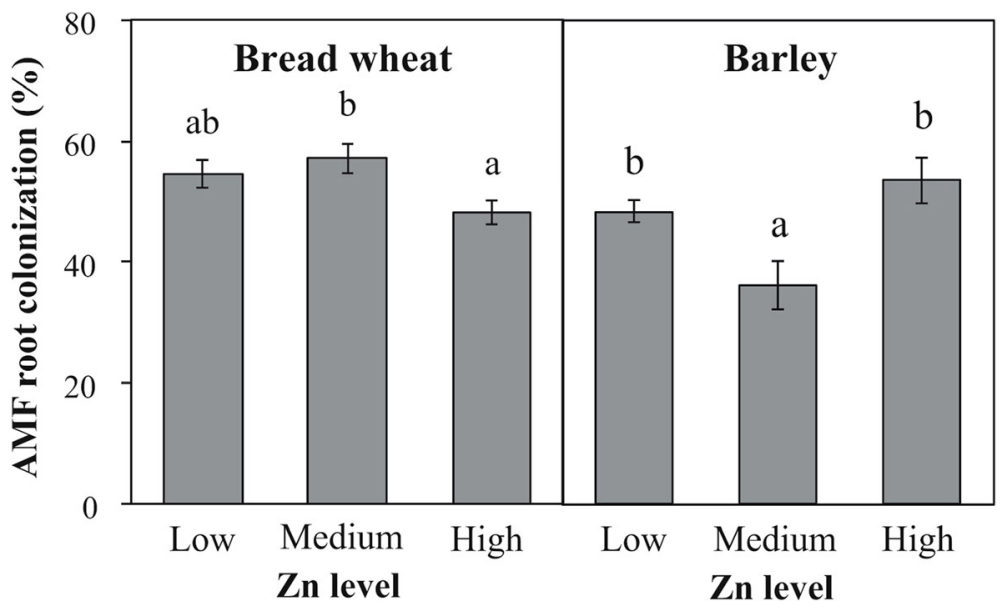

Fig. 1 Effect of Zn application on AMF root colonization of bread wheat and barley sampled at physiological maturity (Zadoks growth stage 90). Values are mean \pm SEM, $n=5$. Means followed by the same letter are not significantly different $(P>0.05$, see text for further details)

was affected by the interaction between AMF inoculation and Zn application, and MKW by AMF inoculation only. The number of kernels per spike was $52 \%$ higher at Low $\mathrm{Zn}$ in plants of barley not inoculated compared to all other treatments (Fig. 2f). Moreover, the MKW was $37 \%$ higher in $+M$ than in $-M$ barley plants (Fig. 2h).

\section{Plant zinc and phosphorus nutrition}

In bread wheat, both grain and straw $\mathrm{Zn}$ concentrations were affected by the interaction between AMF inoculation and $\mathrm{Zn}$ application (Table 1); in the grain, the $-\mathrm{M}$ plants had higher $\mathrm{Zn}$ concentrations than the $+\mathrm{M}$ at each Zn level, respectively (Fig. 3a), and grain Zn concentration ranged from $28.0 \mu \mathrm{g} \mathrm{Zn} \mathrm{g}{ }^{-1}$ (mean Low $\mathrm{Zn}$ ) to $101.18 \mu \mathrm{g} \mathrm{Zn} \mathrm{g}^{-1}$ (mean High $\mathrm{Zn}$ ). In the straw component, there was a sharp increase in $\mathrm{Zn}$ concentration from Low $\mathrm{Zn}$ (mean $7.8 \mu \mathrm{g} \mathrm{Zn} \mathrm{g}{ }^{-1}$ ) to High $\mathrm{Zn}$ (mean of $256.3 \mu \mathrm{g} \mathrm{Zn} \mathrm{g}^{-1}$ ), and at High $\mathrm{Zn}$, concentrations were higher in the $-M$ than the $+M$ plants (Fig. 3c).

The $\mathrm{Zn}$ concentration of barley grain and straw were each affected by the main effect of $\mathrm{Zn}$ application, whereby concentrations increased from Low $\mathrm{Zn}$ to High $\mathrm{Zn}$ (Table 1). For the straw component, the increase in mean $\mathrm{Zn}$ concentration from Low $\mathrm{Zn}$ to High $\mathrm{Zn}$ was marked: from $11.73 \mu \mathrm{g} \mathrm{Zn} \mathrm{g}{ }^{-1}$ up to $472.6 \mu \mathrm{g} \mathrm{Zn} \mathrm{g}^{-1}$ (Fig. 3d). The grain $\mathrm{Zn}$ concentrations were kept within a much smaller range, from $19.14 \mu \mathrm{gn} \mathrm{g}^{-1}$ up to 114.16 $\mu \mathrm{g} \mathrm{Zn} \mathrm{g}^{-1}$ (Fig. 3b).

The $\mathrm{Zn}$ content of bread wheat grain was affected by the interaction between AMF inoculation and $\mathrm{Zn}$ application, while $\mathrm{Zn}$ content in straw was affected by the main effects of AMF inoculation and $\mathrm{Zn}$ application (Table 1). Grain Zn content increased 1.5 fold from Low $\mathrm{Zn}$ to Medium $\mathrm{Zn}$ irrespective of AMF inoculation (on average 24.0 versus $60.8 \mu \mathrm{g}_{\text {plant }}{ }^{-1}$ ), whereas it increased by $85 \%$ from Medium $\mathrm{Zn}$ to High $\mathrm{Zn}$ only in the $-\mathrm{M}$ plants (59.5 versus $110 \mu$ g plant $^{-1}$ ) (Fig. 3e). The accumulation of $\mathrm{Zn}$ in the at High $\mathrm{Zn}$ was lower in the $+\mathrm{M}$ plants than in the $-\mathrm{M}$ plants $\left(77.7\right.$ versus $110.0 \mu \mathrm{g}_{\text {plant }}^{-1}$ ). A similar trend was observed in the straw $\mathrm{Zn}$ content where the $+\mathrm{M}$ plants were lower than that of the $-\mathrm{M}$ plants (mean 109.2 versus $168.3 \mu \mathrm{g}$ plant $^{-1}$, pooling $\mathrm{Zn}$ treatments; Fig. 3g).

As for concentrations, the $\mathrm{Zn}$ content in barley grain and straw was increased by $\mathrm{Zn}$ application (Fig. 3f). Zinc content in grain increased by 280 and $69 \%$ following the increase of $\mathrm{Zn}$ application from Low $\mathrm{Zn}$ to Medium $\mathrm{Zn}$, and again from Medium $\mathrm{Zn}$ to High $\mathrm{Zn}$, respectively (12.2, 46.4 and $78.4 \mu \mathrm{g} \mathrm{plant}{ }^{-1}$ in Low, Medium and High $\mathrm{Zn}$, respectively). A similar trend was found for straw $\mathrm{Zn}$ content $\left(22.5,287.9\right.$ and $977.8 \mu \mathrm{g} \mathrm{plant}{ }^{-1}$ in Low, Medium and High Zn, respectively; Fig. 3h).

In bread wheat, $\mathrm{P}$ content in grain and straw were affected by the interaction between AMF inoculation and $\mathrm{Zn}$ application (Table 1). AMF inoculation lead to a significant increase of grain $\mathrm{P}$ content at Low $\mathrm{Zn}$ and Medium $\mathrm{Zn}(+28 \%$ and $+25 \%$, respectively), while at High Zn level AMF inoculation did not modify P content in grain (Additional file 1: Table S2). At High Zn, the $\mathrm{P}$ content in grain of both $+\mathrm{M}$ and $-\mathrm{M}$ plants $(3.5$ $\mathrm{mg}$ plant $^{-1}$ ) was similar to the values detected in $+\mathrm{M}$ plants grown at lower $\mathrm{Zn}$ availabilities $\left(3.7 \mathrm{mg}\right.$ plant $^{-1}$ ). In the $-\mathrm{M}$ plants, the $\mathrm{P}$ content in straw decreased from $2.9 \mathrm{mg}$ per plant at Low $\mathrm{Zn}$ and Medium $\mathrm{Zn}$ level to 2.1 mg per plant at High Zn (rate of decrease: 26\%). Inoculation by AMF decreased P content in straw at all $\mathrm{Zn}$ applications, but the rate of decrease was different according to $\mathrm{Zn}$ application, ranging from $44 \%$ at Low $\mathrm{Zn}$ and Medium Zn to $29 \%$ High Zn. 


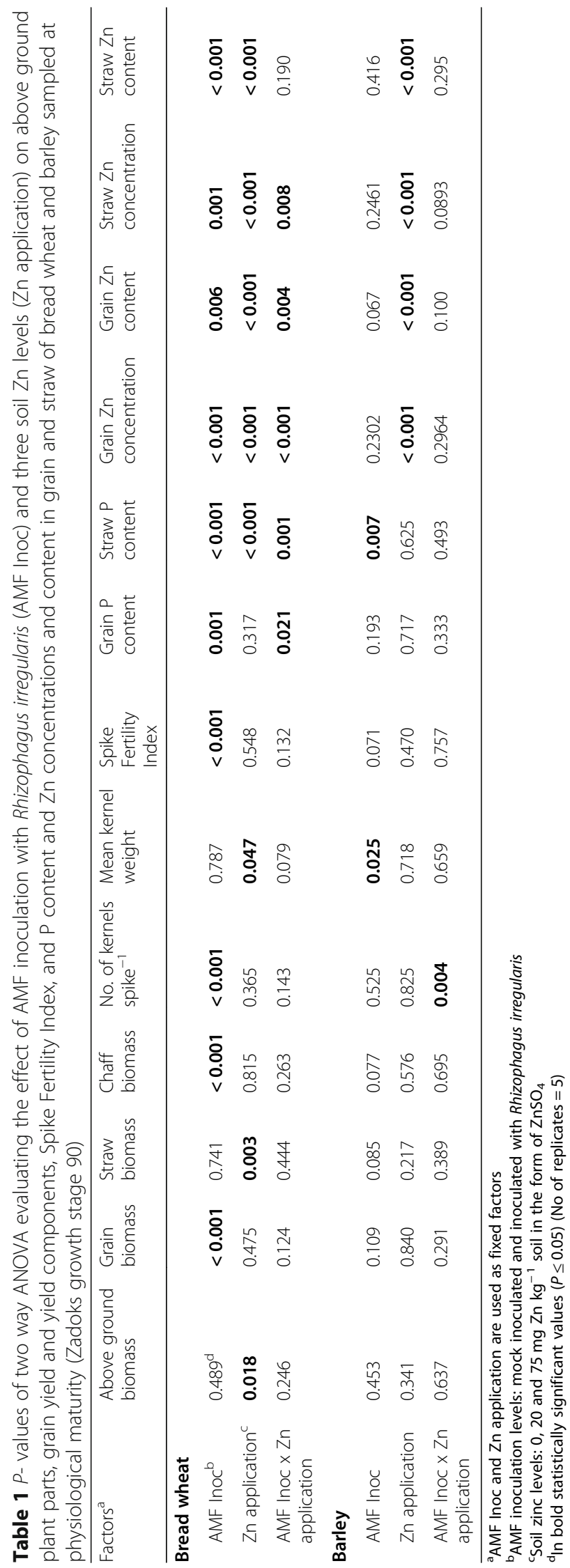



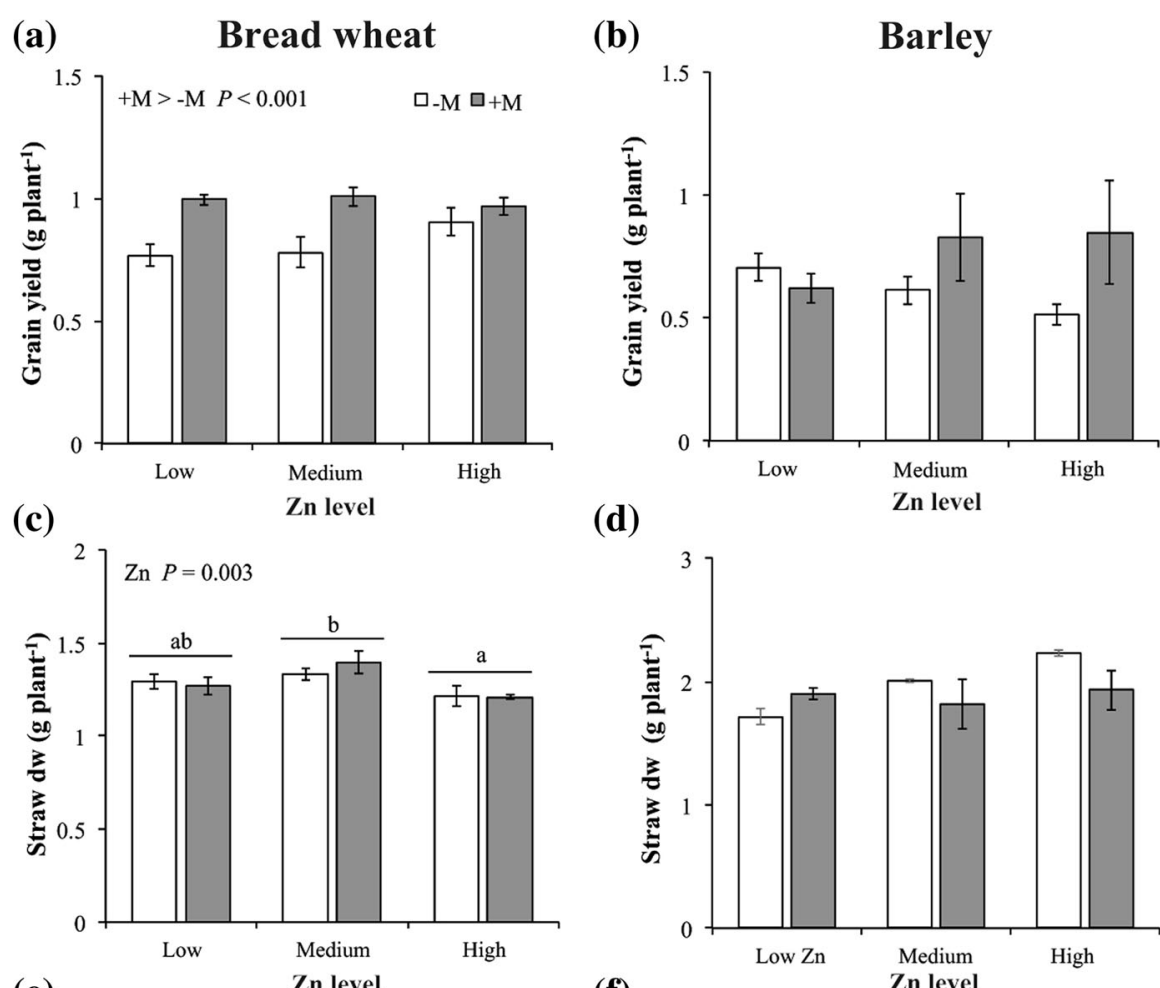

(d)

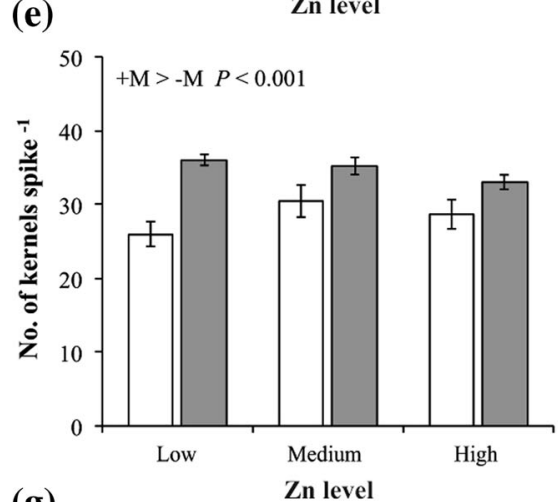

(f)
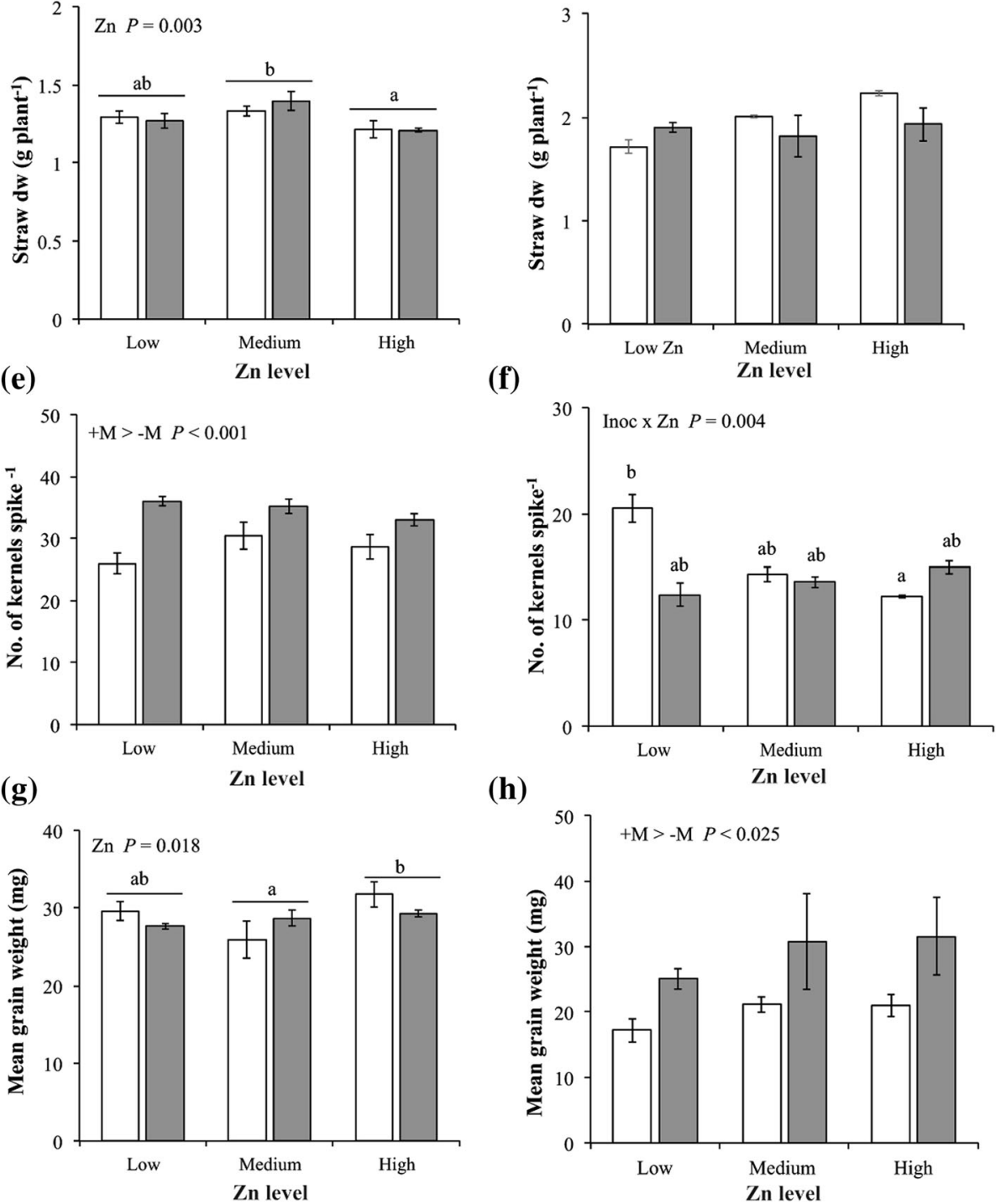

(h)

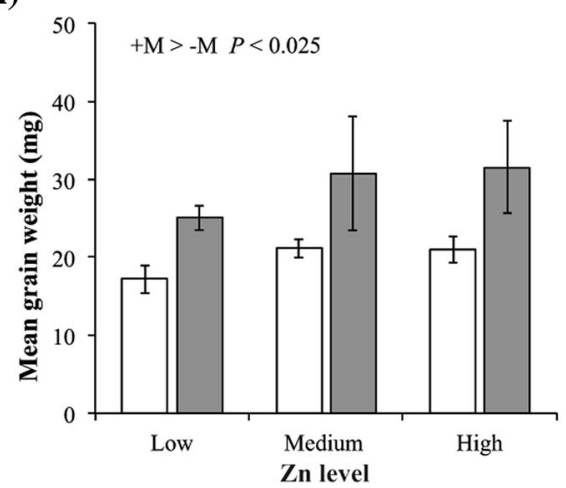

Fig. 2 Effect of Zn application and AMF inoculation with Rhizophagus irregularis (grey bars) or mock-inoculation (white bars) on grain yield, straw dry weight (dw), number of kernels per spike, and mean kernel weight of bread wheat (a, c, e, g, respectively) and barley (b, $d, f, h$, respectively). Plants were sampled at physiological maturity (Zadoks growth stage 90 ). Values are mean $\pm \mathrm{SEM}, n=5$. Means followed by the same letter are not significantly different $(P>0.05$, see text for further details) 
(a) Bread wheat

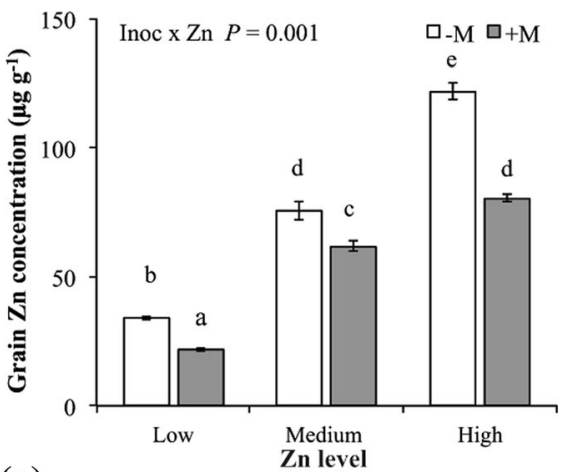

(c)

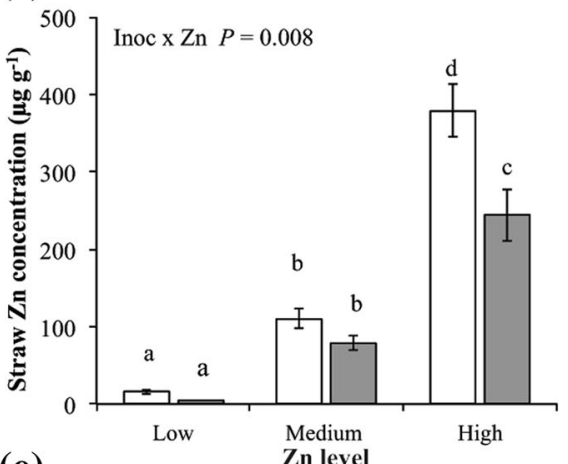

(e)

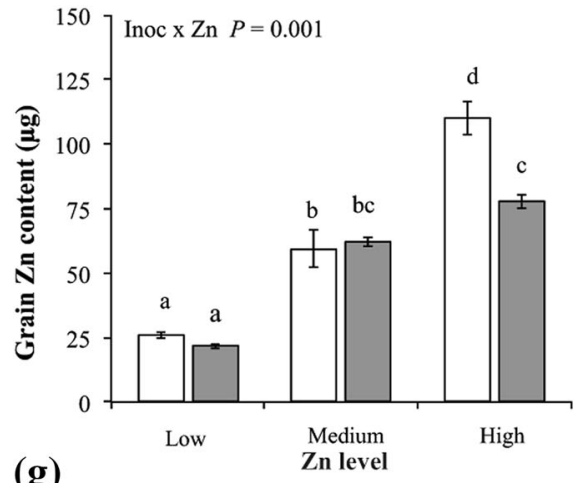

(g)

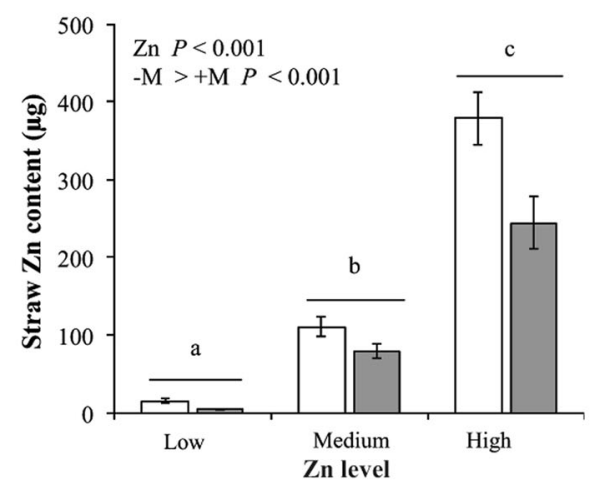

(b)

Barley

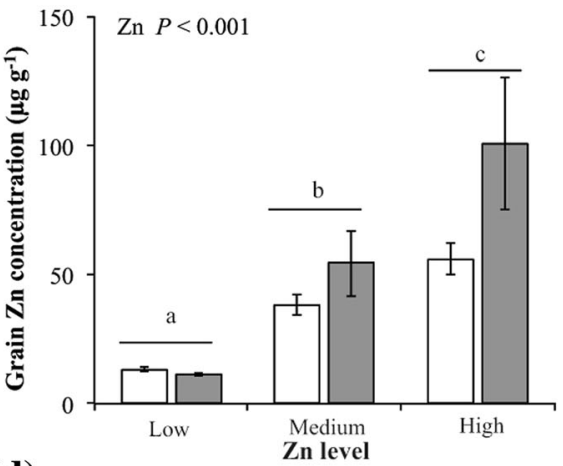

(d)
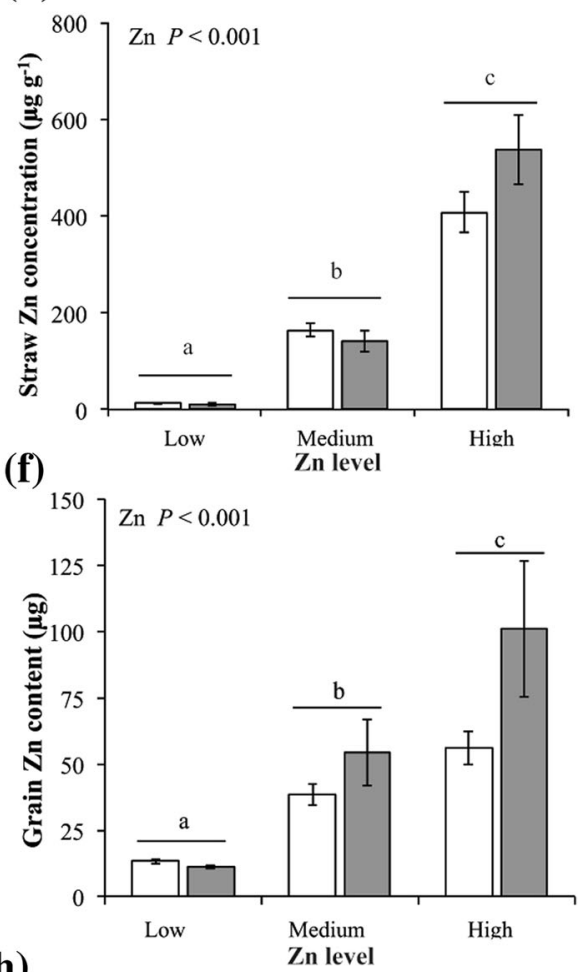

(h)

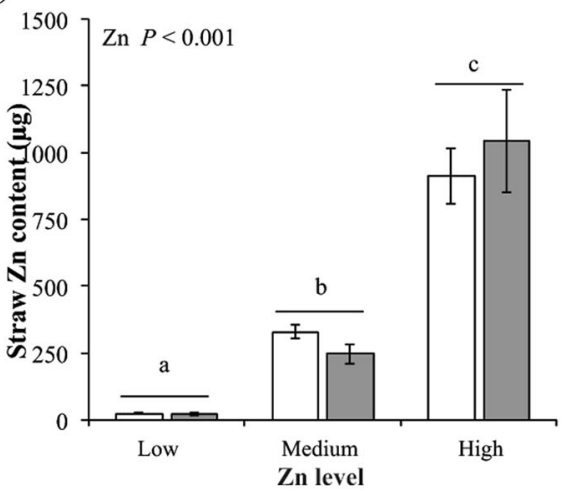

Fig. 3 Effect of Zn application and AMF inoculation with Rhizophagus irregularis (grey bars) or mock-inoculation (white bars) on Zn concentration in grain and straw $(\mathbf{a}, \mathbf{c})$ and on $\mathrm{Zn}$ content in grain and straw $(\mathbf{e}, \mathbf{g})$ in bread wheat, and $\mathrm{Zn}$ concentration in grain and straw $(\mathbf{b}$, d) and on Zn content in grain and straw $(f, h)$ in barley. Plants were sampled at physiological maturity (Zadoks growth stage 90 ). Values are mean \pm SEM, $n=5$. Means followed by the same letter are not significantly different $(P>0.05$, see text for further details) 
In barley, the $\mathrm{P}$ content in grain did not vary according to AMF inoculation or $\mathrm{Zn}$ application, whereas $\mathrm{P}$ content in straw was affected by AMF inoculation (Table 1). In detail, $\mathrm{P}$ content in straw was $26 \%$ higher in the $-\mathrm{M}$ than the $+M$ plants (Additional file 1: Table S3).

\section{Mycorrhizal pathway contribution to zinc uptake in grain and straw}

The activity of ${ }^{65} \mathrm{Zn}$ in the $-\mathrm{M}$ plants was minimal and did not differ from background activity $(P>0.05$; data not shown), confirming that there was no loss of ${ }^{65} \mathrm{Zn}$ out of the HCs. By contrast, the activity in the $+\mathrm{M}$ plants was from seven to nine orders of magnitude higher than background activity $(P<0.05$; data not shown). For this reason, and for the absence of mycorrhizal colonisation in the $-\mathrm{M}$ plants, we excluded the data from mock-inoculated plants in the following calculations and analyses.

In bread wheat, the mycorrhizal pathway of uptake (MPU) of $\mathrm{Zn}$ in grain, straw and total plant (grain + straw) expressed both as $\% \mathrm{Zn}$, and as $\mu \mathrm{g} \mathrm{Zn}$, was significantly affected by $\mathrm{Zn}$ application (Table 2). The percentage of $\mathrm{Zn}$ delivered by MPU in grain did not change between Low $\mathrm{Zn}$ and Medium $\mathrm{Zn}$ (mean value: 8.2\%), whereas it was significantly higher at High $\mathrm{Zn}(27.5 \%)$ (Fig. 4a). Similarly, the percentage of $\mathrm{Zn}$ delivered by MPU to the straw and total plant did not change between Low Zn and Medium Zn (7.8\% and 8.1\%, respectively), whereas it was significantly higher at High $\mathrm{Zn}$ (22.9\% and $24.3 \%$, respectively). Regarding $\mathrm{Zn}$ contents of the grain, straw and total plant, the amount of $\mathrm{Zn}$ delivered by MPU was similar between Low $\mathrm{Zn}$ and Medium $\mathrm{Zn}$, with mean values of 3.4, 3.6 and 7.0 $\mu \mathrm{g} \mathrm{Zn}$

Table 2 -values of one-way ANOVA evaluating the effect of three soil Zn levels on mycorrhizal pathway of Zn uptake (MPU of $\mathrm{Zn})$ in grain, straw and total plant (grain+straw) (\%; $\mu \mathrm{g})$ and on direct pathway of uptake (DPU of Zn) in grain, straw and total plant (grain+straw) $(\mu \mathrm{g})$ of bread wheat and barley inoculated with Rhizophagus irregularis. Plants were sampled at physiological maturity (Zadoks growth stage 90)

\begin{tabular}{lll}
\hline Parameters & Wheat & Barley \\
\hline MPU of $Z n$ in grain $(\%)$ & $\mathbf{0 . 0 4 6 ^ { b }}$ & $\mathbf{0 . 0 1 6}$ \\
MPU of $Z n$ in straw (\%) & $\mathbf{0 . 0 2 4}$ & 0.469 \\
MPU of $Z n$ in total plant $(\%)$ & $\mathbf{0 . 0 3 3}$ & 0.231 \\
MPU of Zn in grain $(\mu \mathrm{g})$ & $<\mathbf{0 . 0 0 1}$ & $\mathbf{0 . 0 0 2}$ \\
MPU of Zn in straw $(\mu \mathrm{g})$ & $<\mathbf{0 . 0 0 1}$ & $<\mathbf{0 . 0 0 1}$ \\
MPU of $Z n$ in total plant $(\mu \mathrm{g})$ & $<\mathbf{0 . 0 0 1}$ & $<\mathbf{0 . 0 0 1}$ \\
DPU of $Z n$ in grain $(\mu \mathrm{g})$ & $<\mathbf{0 . 0 0 1}$ & $\mathbf{0 . 0 1 0}$ \\
DPU of $Z n$ in straw $(\mu \mathrm{g})$ & $<\mathbf{0 . 0 0 1}$ & $<\mathbf{0 . 0 0 1}$ \\
DPU of $Z n$ in total plant $(\mu \mathrm{g})$ & $<\mathbf{0 . 0 0 1}$ & $<\mathbf{0 . 0 0 1}$ \\
\hline
\end{tabular}

${ }^{a}$ Soil zinc levels: 0,20 and $75 \mathrm{mg} \mathrm{kg}^{-1}$ soil in the form of $\mathrm{ZnSO}_{4} .7 \mathrm{H}_{2} \mathrm{O}$

${ }^{b}$ In bold statistically significant values $(P \leq 0.05)$. (No of replicates $=5$ ) $\mu g \mathrm{Zn}$ plant $^{-1}$, respectively. At High Zn, the amount of $\mathrm{Zn}$ delivered by MPU to the grain, straw and total plant (21.4, 51.6 and $73.0 \mu \mathrm{g} \mathrm{Zn} \mathrm{plant}{ }^{-1}$, respectively) was significantly higher than the amounts delivered at Low and Medium Zn.

The direct pathway of $\mathrm{Zn}$ uptake (DPU) in bread wheat was significantly affected by $\mathrm{Zn}$ level (Table 2 ). The amount of $\mathrm{Zn}$ delivered by DPU in grain did not vary between Medium $\mathrm{Zn}$ and High $\mathrm{Zn}$ (mean $57.1 \mu \mathrm{g}$ $\mathrm{Zn}$ plant $^{-1}$ ), but was significantly lower at Low $\mathrm{Zn}$ (19.8 $\mu \mathrm{g} \mathrm{Zn} \mathrm{plant}^{-1}$ ) (Fig. 5a). The amount of $\mathrm{Zn}$ delivered by the DPU to the straw and total plant progressively increased with the increase of $\mathrm{Zn}$ application. At High $\mathrm{Zn}$, the amount of $\mathrm{Zn}$ delivered by DPU to the straw and total plant was 46 and 9 fold higher than at Low $\mathrm{Zn}$, respectively (straw: 4.1 versus $192.2 \mu \mathrm{g} \mathrm{Zn}$ plant ${ }^{-1}$; total plant: 23.9 versus $248.6 \mu \mathrm{g} \mathrm{Zn} \mathrm{plant}^{-1}$ ).

In barley, the MPU of $\mathrm{Zn}$ into the grain, expressed as percentage of total $\mathrm{Zn}$ content, was significantly affected by $\mathrm{Zn}$ application (Table 2); at Low and Medium $\mathrm{Zn}$, the MPU was similar with mean value of $12.3 \%$, and decreased to $7.2 \%$ at High Zn (Fig. $4 \mathrm{~b}$ ). When the MPU

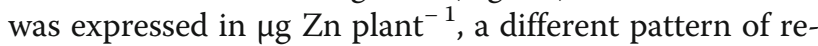
sponse to $\mathrm{Zn}$ application was observed. The MPU for $\mathrm{Zn}$ content in grain, straw and total plant were significantly affected by $\mathrm{Zn}$ application (Table 2). In grain, MPU increased by $360 \%$ from Low $\mathrm{Zn}$ to Medium/High $\mathrm{Zn}$ (1.4 versus $6.5 \mu \mathrm{g} \mathrm{Zn} \mathrm{plant}{ }^{-1}$ ). The MPU to straw and total plant progressively increased from Low through to High Zn. At the highest Zn level, the amount of Zn delivered by the DPU in straw and the total plant was 33and 20-fold higher than at Low $\mathrm{Zn}$, respectively (straw: 1.8 versus $59.2 \mu \mathrm{g} \mathrm{Zn}$ plant $^{-1}$; total plant: 3.2 versus $65.8 \mu \mathrm{g} \mathrm{Zn} \mathrm{plant}{ }^{-1}$ ).

The DPU of $\mathrm{Zn}$ to the grain, straw and total plant in barley was significantly affected by $\mathrm{Zn}$ application (Table 2). The amount of $\mathrm{Zn}$ delivered by DPU to the grain significantly increased between Low $\mathrm{Zn}$ and High Zn (9.8 versus $94.3 \mu \mathrm{g} \mathrm{Zn} \mathrm{plant}{ }^{-1}$ ); the DPU to straw and the total plant also progressively increased with increasing $\mathrm{Zn}$ application (Fig. 5b). At High Zn, the amount of $\mathrm{Zn}$ delivered by DPU to the straw and total plant was 46- and 9-fold higher than at Low Zn, respectively (straw: 19.3 versus $809.3 \mu \mathrm{g} \mathrm{Zn} \mathrm{plant}{ }^{-1}$; total plant: 29.0 versus $903.6 \mu \mathrm{g} \mathrm{Zn} \mathrm{plant}{ }^{-1}$ ).

\section{Discussion}

Here we aimed to fill an important knowledge gap: quantification of the contribution by the mycorrhizal pathway of uptake to $\mathrm{Zn}$ in the grain of bread wheat and barley, under a range of soil $\mathrm{Zn}$ concentrations. We also aimed to study the effects of AMF inoculation on grain yield and nutrition of bread wheat and barley. We discovered that the mycorrhizal pathway of $\mathrm{Zn}$ uptake contributed up to 
(a)

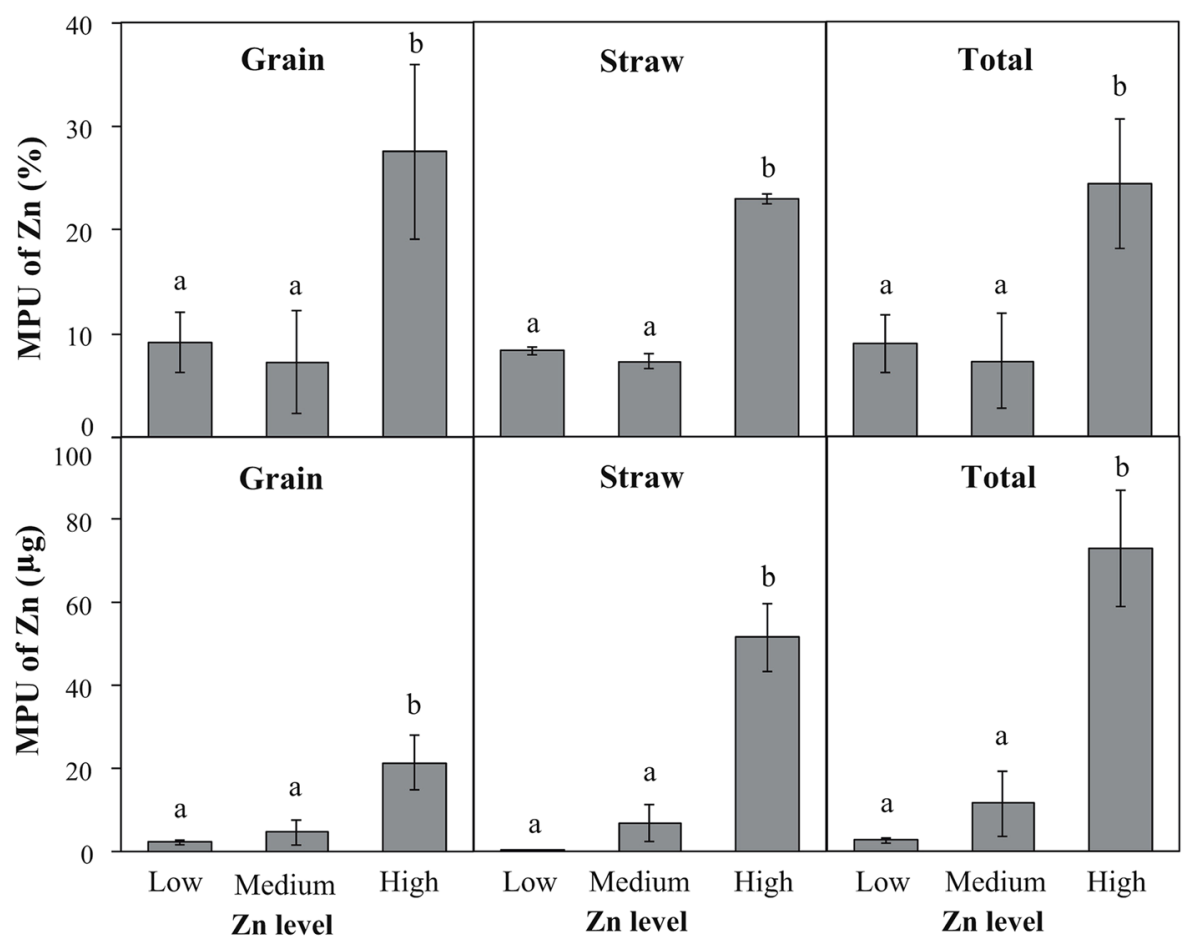

(b)

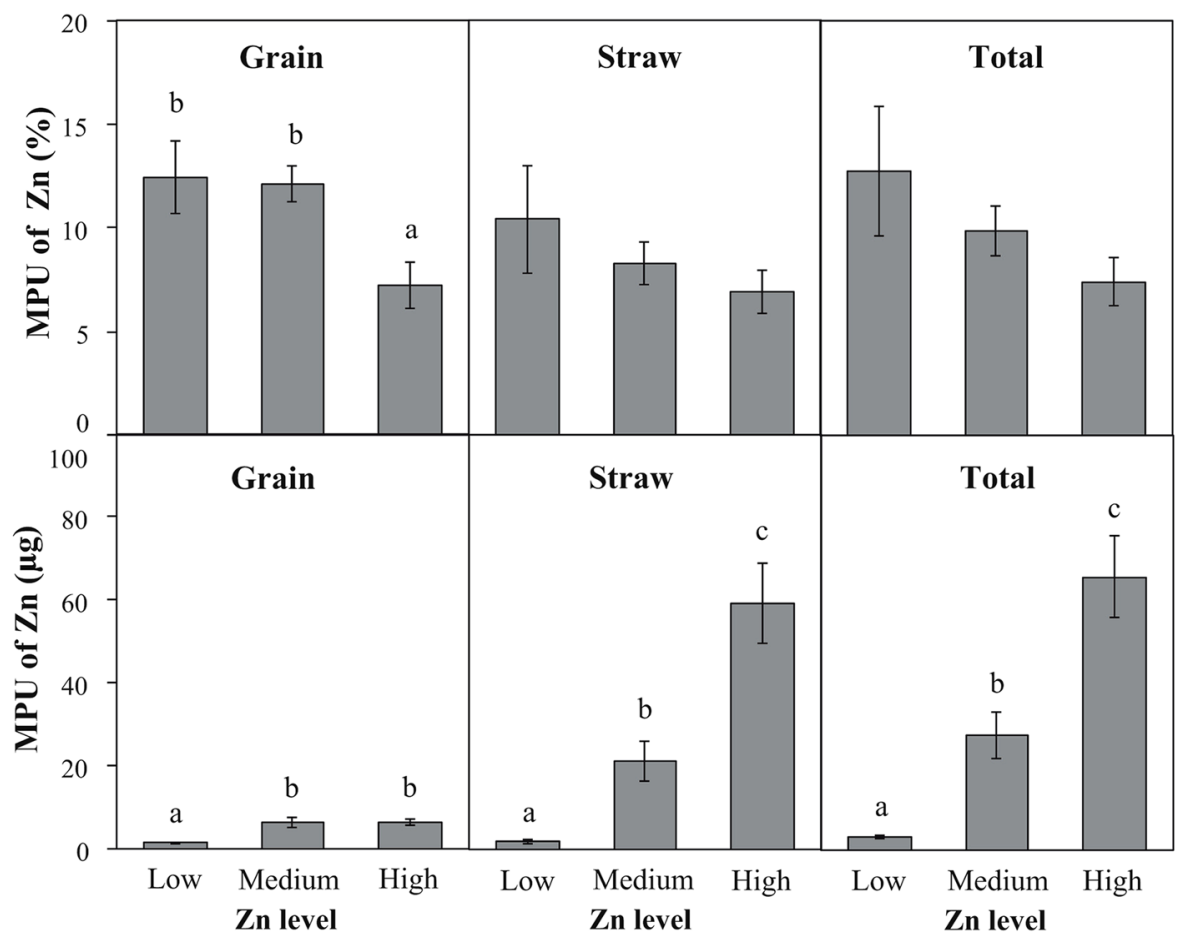

Fig. 4 Effect of $Z n$ application on mycorrhizal pathway of $Z n$ uptake (MPU of $Z n$ ) in grain, straw and total plant (grain + straw) (\% and $\mu \mathrm{g})$ of bread wheat (a) and barley (b). Values are mean $\pm S E M, n=5$. Means followed by the same letter are not significantly different $(P>0.05$, see text for further details)

$24.3 \%$ of the $\mathrm{Zn}$ in bread wheat, and up to $12.7 \%$ of the $\mathrm{Zn}$ in barley; the contribution to $\mathrm{Zn}$ via the mycorrhizal pathway was highly dependent on the soil $\mathrm{Zn}$ concentration.
Results are now discussed in the context of the role of mycorrhizal impacts on yield and nutritional quality of two of the world's major cereal crops. 


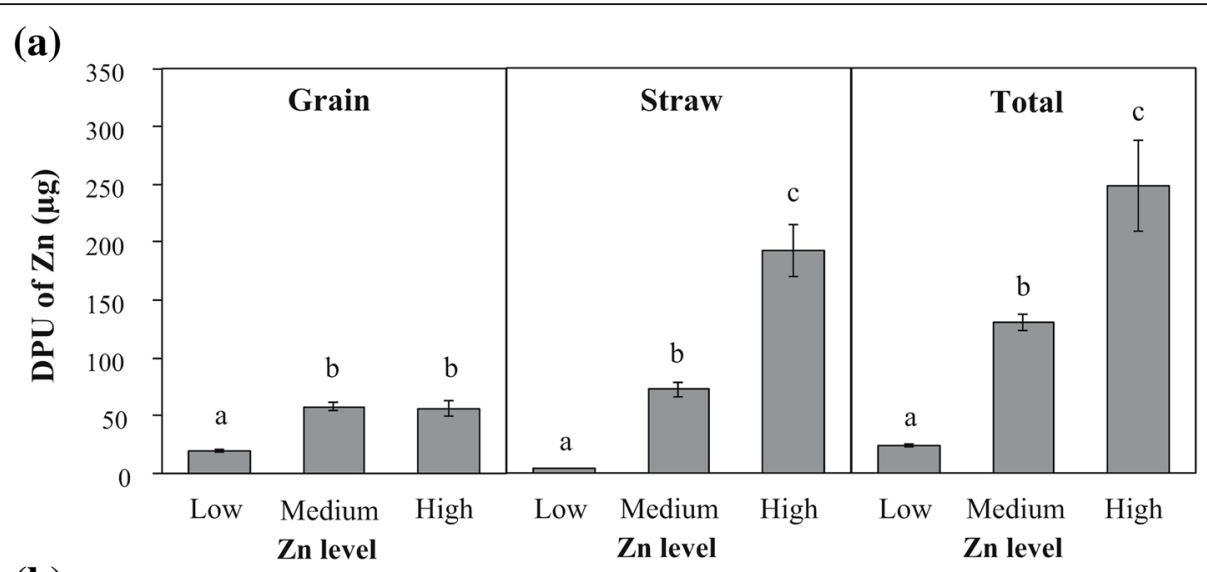

(b)

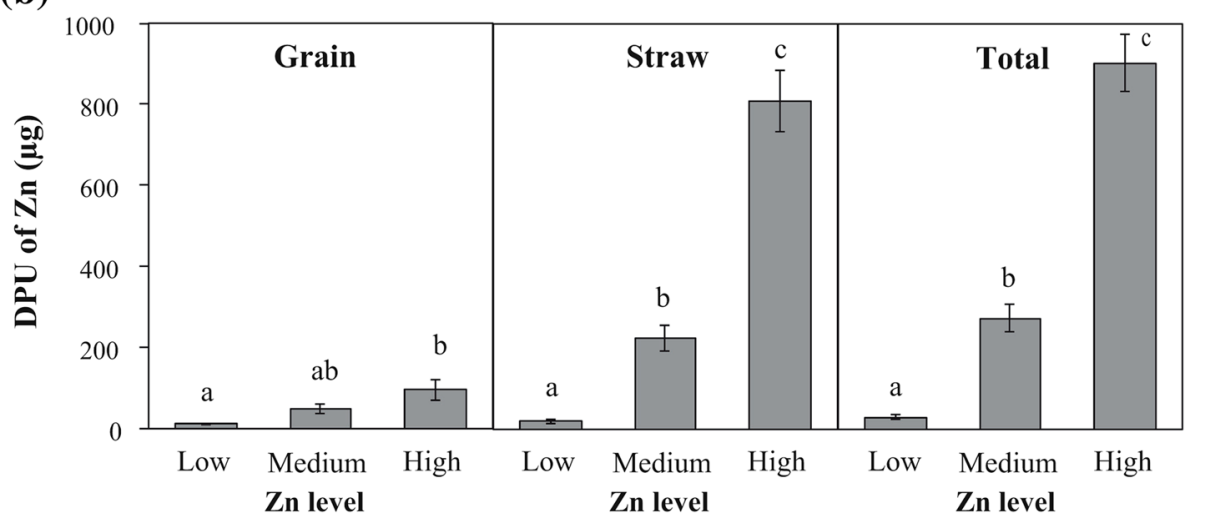

Fig. 5 Effect of Zn application on direct pathway of uptake (DPU of Zn) in grain, straw and total plant (grain + straw) $(\mu \mathrm{g})$ of bread wheat (a) and barley $(\mathbf{b})$. Values are mean $\pm S E M, n=5$. Means followed by the same letter are not significantly different $(P>0.05$, see text for further details)

\section{Arbuscular mycorrhizal fungal colonization}

Both bread wheat and barley plants were well colonized by $R$. irregularis, which is in line with previous work of Al-Karaki and Al-Omoush [1] in wheat, and of Watts-Williams and Cavagnaro [46] using the same barley cultivar. The effects of increasing soil $\mathrm{Zn}$ concentration on mycorrhizal colonization in bread wheat were negative, and variable in barley. Variable impacts of soil $\mathrm{Zn}$ supply for mycorrhizal colonisation have been reported in the literature. For example, the colonisation of wild tobacco roots by AMF increased with increasing $\mathrm{Zn}$ supply in one study [3] whereas in the same soil as the present study, Cavagnaro et al. [7] and Watts-Williams et al. [48] in tomato, observed no impact of soil $\mathrm{Zn}$ concentration on percent colonisation of roots due to $\mathrm{Zn}$ addition in soil, and using the same barley cultivar, Watts-Williams and Cavagnaro [46] found decreased mycorrhizal colonisation with increasing soil $\mathrm{Zn}$.

\section{Cereal growth, yield, and yield components}

Inoculation with $R$. irregularis led to increased grain yield in bread wheat but not in barley, in this study. This is consistent with a recent meta-analysis that reported a positive effect of AMF on wheat yield (17\% increase), but only a neutral effect on barley yield across many field- and glasshouse-based trials [54]. Pellegrino et al. [35] present another meta-analysis showing wheat yield increased due to AMF field inoculation by $20 \%$, from field trials across the world. Consistently, similar yield increases (18\%) were also observed in several bread wheat genotypes field-inoculated with $R$. irregularis [36]. Mycorrhizal plants in the present study also had increased number of grains per spike and decreased chaff, which are desirable traits for improving yield $[15,16]$. The increased grain yield and yield components associated with the formation of AMF in bread wheat may be due to changes in allocation of $\mathrm{P}$ in colonized plants, since the content of $\mathrm{P}$ in grains was greater in inoculated plants compared to the mock-inoculated ones. It must be noted however, that the sandy substrate, small pot size, and exclusive inoculation with $R$. irregularis that were used in this study, are not representative of a field situation, and thus the opportunity to extrapolate the results to a field situation are limited.

\section{Cereal zinc nutrition}

One of the benefits of forming AMF for plants is improved Zn nutrition [9]. Numerous studies, including a 
meta-analysis, have highlighted that inoculation with AMF can lead to increased $\mathrm{Zn}$ concentration in the edible portion of crops including the grain $[17,24,46]$. In the present study, however, grain $\mathrm{Zn}$ concentration was actually reduced in the mycorrhizal bread wheat plants, and unaffected by inoculation in the barley plants. This reduction in $\mathrm{Zn}$ concentration in bread wheat was compensated by increased grain yield in the mycorrhizal plants, leading to similar total $\mathrm{Zn}$ uptake regardless of mycorrhizal inoculation. However, the concentration of grain $\mathrm{Zn}$ is the important factor for improved biofortification outcomes [5] and the consumed products of the grain [13]. Thus, in the present study, AMF inoculation did not present potential for biofortification of the bread wheat or barley.

Although the soil $\mathrm{Zn}$ concentration reached very high levels in the High Zn treatment (DTPA-Zn of $41.4 \mathrm{mg}$ $\mathrm{Zn} \mathrm{kg}^{-1}$ ), we did not observe a positive biomass response to mycorrhizal inoculation in this treatment to suggest that the classic "protective effect" of mycorrhizas at toxic $\mathrm{Zn}$ levels was active, as has been shown in other plant species [10, 11, 23, 47]. In other studies, the protective effect of AMF was observed in M. truncatula at $17 \mathrm{mg} \mathrm{Zn} \mathrm{kg}^{-1}$ soil (DTPA-extractable Zn) [49], tomato at $25 \mathrm{mg} \mathrm{Zn} \mathrm{kg}^{-1}$ soil [7], and in red clover after the addition of $50 \mathrm{mg} \mathrm{Zn} \mathrm{kg}{ }^{-1}$ soil [10]. However, in the present study at the High $\mathrm{Zn}$ level, there appeared to be a protective effect of AMF in terms of relative $\mathrm{Zn}$ allocation to the straw or grain, rather than improvement in biomass accumulation. Importantly, the critical value for the protective effect to engage will be dependent upon soil cation exchange capacity, which affects the bioavailable $\mathrm{Zn}$ that is 'active' for the expression of soil toxicity [45].

\section{The mycorrhizal pathway of zinc uptake}

Our results demonstrated that a substantial proportion of total plant $\mathrm{Zn}$ can be obtained via the mycorrhizal pathway of uptake in cereals. We discovered that the mycorrhizal pathway of Zn uptake (MPU) contributed up to a quarter of the $\mathrm{Zn}$ in bread wheat, and up to an eighth of the $\mathrm{Zn}$ in barley. Our finding that the mycorrhizal pathway of $\mathrm{Zn}$ uptake is important to plant $\mathrm{Zn}$ nutrition in these cereal crops is in agreement with earlier work on a range of plant species.

Our research demonstrated in bread wheat and barley that AMF contribution to plant $\mathrm{Zn}$ increased with increased available soil $\mathrm{Zn}$ in terms of absolute contribution $(\mu \mathrm{g} Z n)$. This is in contrast to data from tracing the MPU of $\mathrm{Zn}$ in tomato, where absolute $\mathrm{Zn}$ contributions remained constant across three different soil Zn concentrations [48]. In the present study, it appears that AMF are unable to regulate the amount of $\mathrm{Zn}$ entering the plant via the MPU, even when $\mathrm{Zn}$ is in excess and potentially detrimental to the plant. This may at least partially explain why we do not see a protective effect of AMF (i.e., increased biomass) in the barley and wheat plants. Although there were differences in proportional contribution via the MPU between wheat and barley at high $\mathrm{Zn}$ concentrations, it is worth noting that the contribution in $\mu \mathrm{g}$ via the mycorrhizal pathway was almost identical between the two species (70 and $66 \mu \mathrm{g} \mathrm{Zn}$ in bread wheat and barley, respectively). Given that the same AMF species contributed the same amount of $\mathrm{Zn}$ to two different plant species, it remains to be seen whether different species of AMF confer different contributions via the MPU. Such studies would inform on whether the colonising AMF species have more of an influence on MPU activity than the species of host plant.

The influence of different species of AMF on enhancing $\mathrm{Zn}$ plant nutrition of wheat was observed by Daei et al. [14]. Barley plants inoculated with Glomus contrictus or Glomus fasciculatus showed an increased Zn uptake, whereas plants inoculated with Glomus margarita did not differ from control plants in $\mathrm{Zn}$ uptake [21]. Moreover, the response of the combination of plant species/genotype and AMF species/isolate would be modulated by other soil properties such as $\mathrm{pH}, \mathrm{N}$ availability, exchangeable calcium and base saturation, and climatic conditions $[12,17,29]$. Thus it is likely that the greater AMF-mediated $\mathrm{Zn}$ uptake in bread wheat compared to barley depends on the higher compatibility and efficiency of the wheat variety with the isolate of $R$. irregularis used.

In bread wheat and barley, the partitioning of the AMF-mediated $\mathrm{Zn}$ uptake within plant tissues changed with $\mathrm{Zn}$ availability in soil. At the lowest $\mathrm{Zn}$ level, 86\% and $44 \%$ of MPU $\mathrm{Zn}$ was allocated to grain in bread wheat and barley, respectively. This proportion decreased to $29 \%$ and $10 \%$ at the highest $\mathrm{Zn}$ level, in bread wheat and barley, respectively. It is possible that this is a result of plants buffering the grain from accumulating high amounts of $\mathrm{Zn}$ under toxic soil $\mathrm{Zn}$ conditions, so as to 'protect' the viability of the seed, as was observed in the same barley cultivar previously [46].

\section{Conclusions}

Here we have quantified for the first time, the mycorrhizal pathway of $\mathrm{Zn}$ uptake to the edible portion of two important cereal crop species. Mycorrhizal fungi can contribute substantially to the $\mathrm{Zn}$ nutrition of cereal crops, but that the contribution cannot be generalised between bread wheat and barley. Furthermore, the contribution by the mycorrhizal pathway was highly dependent on soil $\mathrm{Zn}$ availability, and the relative allocation of $\mathrm{Zn}$ between grain and straw acted independently of mycorrhizal inoculation. The greatest contribution by the mycorrhizal pathway was 
observed at the lowest $\mathrm{Zn}$ addition in barley, and in contrast, the highest $\mathrm{Zn}$ addition in bread wheat. Additionally, the increase of grain yield in mycorrhizal bread wheat by $21.2 \%$ highlights the potential benefits of mycorrhizal fungi for yield, but the $\mathrm{Zn}$ concentration of bread wheat grain was reduced by mycorrhizal inoculation. These results suggest that the role played by AMF on $\mathrm{Zn}$ uptake depends on the functional compatibility between AMF isolate and inoculated cereal species. However, future studies using different cultivars of barley and varieties of bread wheat will provide more information on this hypothesis.

\section{Methods}

\section{Preparation of hyphal compartments, soils, and plants}

A compartmented pot design was used to quantify the contribution of AMF to $\mathrm{Zn}$ uptake in bread wheat and barley, following Watts-Williams et al. [48] (Additional file 1: Figure S1). The hyphal compartments (HCs) were small plastic vials packed with $40 \mathrm{~g}$ soil that had been mixed thoroughly with $428 \pm 12 \mathrm{kBq}$ of ${ }^{65} \mathrm{Zn}$ in the form of ${ }^{65} \mathrm{ZnCl}_{2}$ (Perkin-Elmer, U.S.A.), and then a $10 \mathrm{~g}$ layer of unlabelled soil. The HCs were capped with a $25 \mu \mathrm{m}$ nylon mesh which allowed the penetration of the AMF hyphae but not of the plant roots. The HC lids were then tightly sealed with electrical tape to prevent the penetration of plant roots. A HC was placed in each pot in the same position, with the nylon mesh side facing towards the center of the pot. In addition, plant-free pots $(n=9)$ containing one $\mathrm{HC}$ each were prepared as controls to measure soil $\mathrm{Zn}$ concentration and ${ }^{65} \mathrm{Zn}$ activity at three different $\mathrm{Zn}$ concentration treatments (Low, Medium, and High Zn, replicated three times). Plastic $1 \mathrm{~L}$ pots were filled with $1.4 \mathrm{~kg}$ of a 9:1 $(w / w)$ sand/soil mixture containing $140 \mathrm{~g}$ of $R$. irregularis WFVAM10 inoculum, or of mock inoculum performing as a non-mycorrhizal control. The $R$. irregularis WFVAM10 is synonymous with DAOM 181602, an earlier voucher number for DAOM 197198, formerly named Glomus intraradices, originally from subcultured from an axenic culture on transformed roots obtained from Professor J. A. Fortin, University of Montreal, Canada. The $R$. irregularis inoculum was added as a mix of dry soil, fungal spores and external hyphae, and root fragments of Marigold (Tagetes patula) pot cultures produced on-site. The control, a mock inoculum, was a mixture of dry soil and root fragments of Marigold pots that had not been inoculated with AMF; the inoculum was grown on the same sand/soil substrate that makes up the other $90 \%$ of the pot, so the proportional volume was the same as for mass (one tenth, or $100 \mathrm{~mL}$ in the $1 \mathrm{~L}$ plastic pot). The soil was collected from the Mallala region of South
Australia [48], and the chemical characteristics of the soil were as follows: $\mathrm{pH}_{1: 5}$ (water) 7.1 ; plant available (Olsen) P $16 \mathrm{mg} \mathrm{kg}^{-1}$, and DTPA- extractable Zn 0.65 $\mathrm{mg} \mathrm{kg}^{-1}$ [25]. The soil was firstly sieved to $<2 \mathrm{~mm}$ and the sand/soil mixture was sterilised by autoclaving (121 ${ }^{\circ} \mathrm{C}$ for $25 \mathrm{~min}$, twice). The sand/soil mixture, which is referred to as 'soil' hereafter, was amended with 20 or $75 \mathrm{mg} \mathrm{Zn} \mathrm{kg}{ }^{-1}$ soil, in the form of $\mathrm{ZnSO}_{4} \cdot 7 \mathrm{H}_{2} \mathrm{O}$ solution. These treatments are henceforth referred to as Medium $\mathrm{Zn}$ and High $\mathrm{Zn}$ treatments, respectively. After the application of $\mathrm{Zn}$ to soil, the plant-available (DTPA-extractable) $\mathrm{Zn}$ [25] concentrations were $12.9 \pm$ $1.2 \mathrm{mg} \mathrm{Zn}$ and $41.4 \pm 2.7 \mathrm{mg} \mathrm{Zn} \mathrm{kg}{ }^{-1}$ soil, for the Medium $\mathrm{Zn}$ and High $\mathrm{Zn}$ treatments, respectively. In addition, the Low $\mathrm{Zn}$ treatment had no $\mathrm{Zn}$ application, and its DTPA-extractable $\mathrm{Zn}$ concentration was $0.19 \pm$ $0.07 \mathrm{mg} \mathrm{Zn} \mathrm{kg}^{-1}$ soil. All pots were fertilized with 25 mg of anhydrous $\mathrm{CaHPO}_{4} \mathrm{~kg}^{-1}$ soil in order to stimulate plant growth in the otherwise low nutrient soil, without inhibiting AMF colonization.

Seeds of bread wheat (Triticum aestivum L.) cv. Axe (obtained from Australian Grain Technologies), and two-rowed barley (Hordeum vulgare L.) cv. Compass (originally obtained from the Barley Breeding Program, University of Adelaide), were surface-sterilised by immersion in $10 \%$ sodium hypochlorite solution for 10 min, and rinsed three times with deionized (DI) water. Seeds were pre-germinated on moist filter paper in a Petri dish for 2 days at $25^{\circ} \mathrm{C}$ in the dark, and two pre-germinated seeds were planted into each pot. After one week the seedlings were thinned to one per pot. Plants were grown in a controlled environment glasshouse at the University of Adelaide's Waite campus, during the months May-July 2017. Over this period, glasshouse mean maximum temperature was $21.2 \pm 0.14$ ${ }^{\circ} \mathrm{C}$, and mean minimum temperature was $8.2 \pm 0.30{ }^{\circ} \mathrm{C}$. All pots were watered twice per week with reverse osmosis (RO) water, and from week two were fertilised once per week with a $1 / 10$ strength modified Long Ashton solution (omitting P and $\mathrm{Zn}$ ) [8].

The plants were additionally fertilized with a total of $50 \mathrm{mg}$ of nitrogen $(\mathrm{N})$ per pot as $\mathrm{NH}_{4} \mathrm{NO}_{3}$ over the course of the experiment: $25 \mathrm{mg} \mathrm{N}$ was applied at pseudo-stem stage (Zadoks growth stage (GS) 30), and $25 \mathrm{mg} \mathrm{N}$ at flag leaf sheath opening stage (GS47) [52]. The experiment was a completely randomized design with a factorial combination of two treatments (AMF inoculation and soil $\mathrm{Zn}$ application) and five biological replicates per treatment, resulting in 30 wheat plants and 30 barley plants.

\section{Soil nutrient analysis}

At physiological maturity (GS90), soil samples taken from the $\mathrm{HCs}$ placed into plant-free pots were 
oven-dried $\left(105^{\circ} \mathrm{C}\right.$ for $\left.48 \mathrm{~h}\right)$ and digested with aqua regia (following Zarcinas et al., 1996), for the determination of total soil $\mathrm{Zn}$ concentration. Additional soil samples were analysed for DTPA-extractable Zn [25]. Zinc concentrations in the digests and extracts was then determined by inductively-coupled plasma atomic emission spectrophotometry (ICP-AES, Spectroflame Modula, Spectro, Germany). Additionally, ${ }^{65} \mathrm{Zn}$ activity in the digests was measured by $\gamma$-spectroscopy (1480 Wizard $\mathrm{TM}^{\circ}$, Wallac, Germany).

\section{Harvesting and plant physiological analyses}

Plants were destructively harvested at physiological maturity (GS90) after 73 and 83 days from transplanting for bread wheat and barley, respectively. Plants were cut at ground level and partitioned into grain, chaff and straw and subsequently oven-dried $\left(60^{\circ} \mathrm{C}\right.$ for $48 \mathrm{~h}$ ) for dry weight determination. Mean kernel dry weight was measured and number of kernels per spike and Spike Fertility Index (SFI) were calculated. The SFI is the ratio of number of kernels per spike to chaff dry weight per spike. Grain and straw samples were digested following Zarcinas et al. [53], prior to quantification of $\mathrm{P}$ and $\mathrm{Zn}$ concentrations by ICP-AES, and of plant ${ }^{65} \mathrm{Zn}$ activity by $\gamma$-spectroscopy as described for soil (above). Due to the high $\gamma$ emission measured in the pots (over $2 \mu \mathrm{S} \mathrm{h}^{-1}$ ), the entire root systems could not be safely removed. Consequently, a sample of roots was collected from each pot by coring the soil $(15 \mathrm{~mm}$ diameter and $120 \mathrm{~mm}$ depth). Roots were then carefully washed from the soil with RO water, and placed into $50 \% \mathrm{C}_{2} \mathrm{H}_{6} \mathrm{O}$ (ethanol) prior to be cleared with $\mathrm{KOH}(10 \% w / v)$ [38] and stained with 5\% ink in vinegar [44]. Stained roots were used for assessing AMF colonization by the gridline intersect method [28].

\section{Calculations}

The activity of ${ }^{65} \mathrm{Zn}$ in mock-inoculated plants did not differ from background activity. Therefore, we calculated for bread wheat and barley the mycorrhiza-mediated contribution to $\mathrm{Zn}$ uptake (mycorrhizal pathway of $\mathrm{Zn}$ uptake: MPU $\mathrm{Zn}$ ) in grain and straw (as \% and $\mu \mathrm{g} \mathrm{Zn}$ ) using the specific activity (SA) values of ${ }^{65} \mathrm{Zn}$ in the soil and in the inoculated plants.

The SA in grain, straw and soil were calculated using the following equations (following [48]):

$$
\begin{aligned}
& \text { Grain/straw specific activity } \\
& =\frac{{ }^{65} \mathrm{Zn} \text { activity }\left(\mathrm{kBqg}^{-1} \text { grain } / \text { straw dry weight }\right)}{\mathrm{Zn}\left(\mu \mathrm{gg}^{-1} \text { grain } / \text { straw }\right)}
\end{aligned}
$$

$$
\begin{aligned}
& \text { Soil specific activity } \\
& \qquad=\frac{{ }^{65} \mathrm{Zn} \text { activity }\left(\mathrm{kBq} \mathrm{g}^{-1} \text { soil }\right)}{\text { Soil DTPA }- \text { extractable } \mathrm{Zn}\left(\mu g^{-1} \text { soil }\right)}
\end{aligned}
$$

On the basis of Smith et al. [40] it was assumed that the AMF hyphal growth measured as hyphal length density in the extra $\mathrm{HCs}$ was similar to the growth in the whole pot. Therefore, the MPU $\mathrm{Zn}$ in grain and straw was calculated as follows:

$$
\begin{aligned}
& \text { MPU Zn grain/straw }(\%) \\
& =\frac{\text { Equation } 1 a}{\text { Equation } 1 b} \times \frac{\text { Total soil weight }}{65 \mathrm{Zn} \text { labelled soil weight }} \times 100
\end{aligned}
$$

where total soil weight is the dry weight of the soil $(1,400$ g) in the whole pot and ${ }^{65} \mathrm{Zn}$ labelled soil weight is the dry weight of the ${ }^{65} \mathrm{Zn}$-labelled soil in the HC (40 g).

$$
\begin{aligned}
& \text { MPU Zn grain } / \text { straw }(\mu \mathrm{g}) \\
& =\frac{\text { Grain } / \text { straw Zn content }(\mu \mathrm{g}) x \text { Equation } 2}{100}
\end{aligned}
$$

The contribution of the DPU to Zn uptake in bread wheat and barley was calculated by the difference between total grain/straw $\mathrm{Zn}$ content $(\mu \mathrm{g})$ and MPU Zn grain/straw content $(\mu \mathrm{g})$. The total MPU contribution to $\mathrm{Zn}$ uptake $(\mu \mathrm{g})$ as well the direct contribution of roots to $\mathrm{Zn}$ uptake (DPU; $\mu \mathrm{g}$ ) were calculated as the sum of grain MPU/DPU Zn and straw MPU/DPU Zn. MPU Zn (\%) was calculated as the ratio of MPU $\mathrm{Zn}$ uptake $(\mu \mathrm{g})$ to total plant $\mathrm{Zn}$ content.

\section{Statistics and data analyses}

Mycorrhizal colonisation of roots (\% colonized root length), MPU and DPU $\mathrm{Zn}$ in grain and straw (\% and $\mu \mathrm{g}$ ), and total MPU and DPU Zn (\% and $\mu \mathrm{g}$ ) were analysed by one-way ANOVA, with Zn application used as fixed factor. We did not include the data from mock-inoculated plants in the statistical analysis of \% colonized root length and MPU to $\mathrm{Zn}$ because the roots were not colonized and had no ${ }^{65} \mathrm{Zn}$ activity. Above-ground dry weight, yield, yield components, and $\mathrm{Zn}$ and $\mathrm{P}$ content in grain and straw were analysed by two-way ANOVA, with AMF inoculation and Zn application the fixed factors. The one-way and two-way ANOVA data were $\ln$ - or arcsine-transformed when needed, to fulfil the assumptions of ANOVA. Where significant differences were found, the Tukey's B post hoc test was performed to assess the differences among means. Mean and standard error value given in Tables and Figures represent non-transformed data. All data were analysed using SPSS 23.0 software (SPSS Inc., Chicago, IL). 


\section{Additional file}

Additional file 1: Supplementary materials to the manuscript including a Table of ANOVA outcomes, two Tables of plant response data (yield parameters and $\mathrm{P}$ contents), and one Figure depicting the experimental pot and hyphal compartment set-up. (DOCX $119 \mathrm{~kb}$ )

\section{Abbreviations}

AMF: Arbuscular mycorrhizal fungi; RO: Reverse osmosis

\section{Acknowledgements}

The authors would like to thank Ms. Sonia Grocke, Ms. Rebecca Stonor, Ms. Bogumila Tomczack, Ms. Caroline Johnston and Prof Steve Tyerman for their assistance in running the experiment and valuable discussions.

\section{Funding}

AC was supported by a PhD scholarship from Scuola Superiore Sant'Anna and SJWW was supported by the University of Adelaide Ramsay Fellowship and the Australian Research Council Centre of Excellence in Plant Energy Biology (\# CE140100008).

\section{Availability of data and materials}

The datasets used and/or analysed during the current study are available from the corresponding author on reasonable request.

\section{Authors' contributions}

Conceived and designed the experiments: SJWW TRC EP LE. Performed the experiments: AC SJWW. Analyzed the data: AC EP LE. Wrote the paper: AC TRC EP LE SJWW. Isotope additions and analysis: SJWW AC MJM. Edited and approved the final manuscript version: AC TRC EP LE MJM SJWW.

\section{Ethics approval and consent to participate}

Not applicable.

\section{Consent for publication}

Not applicable.

\section{Competing interests}

The authors declare that they have no competing interests.

\section{Publisher's Note}

Springer Nature remains neutral with regard to jurisdictional claims in published maps and institutional affiliations.

\section{Author details}

${ }^{1}$ Institute of Life Sciences, Scuola Superiore Sant'Anna, Piazza Martiri della Libertà 33, 56127 Pisa, Italy. ${ }^{2}$ The School of Agriculture, Food and Wine, and the Waite Research Institute, The University of Adelaide, PMB 1, Glen Osmond, South Australia 5064, Australia. ${ }^{3}$ Australian Research Council Centre of Excellence in Plant Energy Biology, The University of Adelaide, Glen Osmond, South Australia, Australia.

Received: 23 August 2018 Accepted: 27 March 2019

Published online: 10 April 2019

\section{References}

1. Al-Karaki GN, Al-Omoush M. Wheat response to phosphogypsum and mycorrhizal fungi in alkaline soil. J Plant Nutr. 2002;25:873-83.

2. Alloway BJ. Soil factors associated with zinc deficiency in crops and humans. Environ Geochem Health. 2009;31:537-48.

3. Audet P, Charest C. Effects of AM colonization on "wild tobacco" plants grown in zinc-contaminated soil. Mycorrhiza. 2006;16:27-283.

4. Cakmak I, Kutman UB. Agronomic biofortification of cereals with zinc: a review. Eur J Soil Sci. 2018;69:172-80.

5. Cakmak I, McLaughlin MJ, White P. Zinc for better crop production and human health. Plant Soil. 2017:411:1-4.

6. Cakmak I. Enrichment of cereal grains with zinc: agronomic or genetic biofortification? Plant Soil. 2008;302:1-17.
7. Cavagnaro TR, Dickson S, Smith FA. Arbuscular mycorrhizas modify plant responses to soil zinc addition. Plant Soil. 2010:329:307-13.

8. Cavagnaro TR, Smith FA, Lorimer MF, Haskard KA, Ayling SM, Smith SE. Quantitative development of Paris-type arbuscular mycorrhizas formed between Asphodelus fistulosus and Glomus coronatum. New Phytol. 2001; 149:105-13.

9. Cavagnaro TR. The role of arbuscular mycorrhizas in improving plant zinc nutrition under low soil zinc concentrations: a review. Plant Soil. 2008;304: 315-25.

10. Chen BD, Li XL, Tao HQ, Christie P, Wong MH. The role of arbuscular mycorrhiza in zinc uptake by red clover growing in a calcareous soil spiked with various quantities of zinc. Chemosphere. 2003;50:839-46.

11. Christie $\mathrm{P}, \mathrm{Li} X$, Chen B. Arbuscular mycorrhiza can depress translocation of zinc to shoots of host plants in soils moderately polluted with zinc. Plant Soil. 2004:261:209-17.

12. Ciccolini $V$, Bonari $E$, Pellegrino E. Land-use intensity and soil properties shape the composition of fungal communities in Mediterranean peaty soils drained for agricultural purposes. Biol Fertil Soils. 2015;51:719-31.

13. Ciccolini V, Pellegrino E, Coccina A, Fiaschi Al, Cerretani D, Sgherri C, Quartacci MF, Ercoli L. Biofortification with iron and zinc improves nutritional and nutraceutical properties of common wheat flour and bread. J Agric Food Chem. 2017;65:5443-52.

14. Daei G, Ardekani MR, Rejali F, Teimuri S, Miransari M. Alleviation of salinity stress on wheat yield, yield components, and nutrient uptake using arbuscular mycorrhizal fungi under field conditions. J Plant Physiol. 2009; 166:617-25.

15. Ercoli L, Arduini I, Mariotti M, Lulli L, Masoni A. Management of Sulphur fertiliser to improve durum wheat production and minimise $S$ leaching. Eur J Agron. 2012;38:74-82.

16. Ercoli L, Masoni A, Pampana S, Mariotti M, Arduini I. As durum wheat productivity is affected by nitrogen fertilisation management in Central Italy. Eur J Agron. 2013:44:38-45.

17. Ercoli L, Schüßler A, Arduini I, Pellegrino E. Strong increase of durum wheat iron and zinc content by field-inoculation with arbuscular mycorrhizal fungi at different soil nitrogen availabilities. Plant Soil. 2017;419:153-67.

18. Göhre V, Paszkowski U. Contribution of the arbuscular mycorrhizal symbiosis to heavy metal phytoremediation. Planta. 2006;223:1115-22.

19. Hess SY. National Risk of zinc deficiency as estimated by National Surveys. Food Nutr Bull. 2017;38:3-17.

20. Jansa J, Mozafar A, Frossard E. 2003. Long-distance transport of $P$ and $Z n$ through the hyphae of an arbuscular mycorrhizal fungus $n$ symbiosis with maize. Agronomie EDP Sciences 23, 481-488.

21. Jensen A. Influence of four vesicular-arbuscular mycorrhizal Fungi on nutrient uptake and growth in barley (Hordeum Vulgare). New Phytol. 1982; 90:45-50.

22. Kaiser C, Kilburn MR, Clode PL, Fuchslueger L, Koranda M, Cliff JB, Solaiman ZM, Murphy DV. Exploring the transfer of recent plant photosynthates to soil microbes: mycorrhizal pathway vs direct root exudation. New Phytol. 2015:205:1537-51.

23. Lee YJ, George E. Contribution of mycorrhizal hyphae to the uptake of metal cations by cucumber plants at two levels of phosphorus supply. Plant Soil. 2005;278:361-70.

24. Lehmann A, Veresoglou SD, Leifheit EF, Rillig MC. Arbuscular mycorrhizal influence on zinc nutrition in crop plants - a meta-analysis. Soil Biol Biochem. 2014;69:123-31.

25. Lindsay WL, Norvell WA. Development of a DTPA soil test for zinc, Iron, manganese, and Copper1. Soil Sci Soc Am J. 1978;42:421-8.

26. Lindsay WL. Zinc in soils and plant nutrition. In: Advances in agronomy: Academic Press; 1972. p. 147-86.

27. Lingua G, Franchin C, Todeschini V, Castiglione S, Biondi S, Burlando B, Parravicini V, Torrigiani P, Berta G. Arbuscular mycorrhizal fungi differentially affect the response to high zinc concentrations of two registered poplar clones. Environ Pollut. 2008;153:137-47.

28. McGonigle TP, Miller MH, Evans DG, Fairchild GL, Swan JA. A new method which gives an objective measure of colonization of roots by vesicular_arbuscular mycorrhizal fungi. New Phytol. 1990;115:495-501.

29. Medeiros CAB, Clark RB, Ellis EJ. Growth and nutrient uptake of sorghum cultivated with vesicular-arbuscular. Mycorrhiza. 1994:4:85-191.

30. Meier S, Cornejo P, Cartes P, Borie F, Medina J, Azcon R. Interactive effect between cu-adapted arbuscular mycorrhizal fungi and biotreated agrowaste residue to improve the nutritional status of Oenothera 
picensis growing in cu-polluted soils. J Plant Nutr Soil Sci. 2015;178: 126-35.

31. Myers SS, Zanobetti $\mathrm{A}$, Kloog I, et al. Increasing $\mathrm{CO}_{2}$ threatens human nutrition. Nature. 2014;510:139-42.

32. Palmgren MG, Clemens S, Williams LE, Krämer U, Borg S, Schjørring JK, Sanders D. Zinc biofortification of cereals: problems and solutions. Trends Plant Sci. 2008;: :464-73.

33. Pellegrino E, Bedini S. Enhancing ecosystem services in sustainable agriculture: biofertilization and biofortification o chickpea (Cicer arietinum L.) by arbuscular mycorrhizal fungi. Soil Biol Biochem. 2014;68:429-39.

34. Pellegrino E, Bosco S, Ciccolini V, Pistocchi C, Sabbatini T, Silvestri N, Bonari E. Agricultural abandonment in Mediterranean reclaimed peaty soils: longterm effects on soil chemical properties, arbuscular mycorrhizas and $\mathrm{CO}_{2}$ flux. Agric Ecosyst Environ. 2015a;199:164-75.

35. Pellegrino E, Öpik M, Bonari E, Ercoli L. Responses of wheat to arbuscular mycorrhizal fungi: a meta-analysis of field studies from 1975 to 2013 . Soil Biol Biochem. 2015b;84:210-7.

36. Pellegrino E, Schüßler A, Coccina A, Ercoli L. Variability in the response to arbuscular mycorrhizal fungi and biofortification supports the selection of common wheat genotypes for enhancing iron and zinc concentration in grain: Submitted to Plant and Soil.

37. Pfeiffer WH, McClafferty B. HarvestPlus: breeding crops for better nutrition. Crop Sci. 2007:47:S-88.

38. Phillips JM, \& Hayman DS. Improved procedures for clearing roots and staining parasitic and vesicular-arbuscular mycorrhizal fungi for rapid assessment of infection. Transactions of the British mycological Society. 1970:55(1):158-IN18.

39. Smith SE, Read D. Mycorrhizal Symbiosis. New York: Academic Press; 2008.

40. Smith SE, Smith FA, Jakobsen I. Mycorrhizal fungi can dominate phosphate supply to plants irrespective of growth responses. Plant Physiol. 2003;133: $16-20$.

41. Tamayo E, Gómez-Gallego T, Azcón-Aguilar C, Ferrol N. Genome-wide analysis of copper, iron and zinc transporters in the arbuscular mycorrhizal fungus Rhizophagus irregularis. Front Plant Sci. 2014;5:547.

42. Velu G, Ortiz-Monasterio I, Cakmak I, Hao Y, Singh RP. Biofortification strategies to increase grain zinc and iron concentrations in wheat. J Cereal Sci. 2014;59:365-72.

43. Velu G, Singh RP, Huerta-Espino J, et al. Performance of biofortified spring wheat genotypes in target environments for grain zinc and iron concentrations. Field Crop Res. 2012;137:261-7.

44. Vierheilig H, Coughlan AP, Wyss URS, \& Piché Y. Ink and vinegar, a simple staining technique for arbuscularmycorrhizal fungi. Appl Environ Microbiol. 1998;64(12):5004-7.

45. Warne MSJ, Heemsbergen D, Stevens D, et al. Modeling the toxicity of copper and zinc salts to wheat in 14 soils. Environ Toxicol Chem. 2008;27: 786-92.

46. Watts-Williams SJ, Cavagnaro TR. Arbuscular mycorrhizal fungi increase grain zinc concentration and modify the expression of root ZIP transporter genes in a modern barley (Hordeum vulgare) cultivar. Plant Sci. 2018;274:163-70.

47. Watts-Williams SJ, Patti AF, Cavagnaro TR. Arbuscular mycorrhizas are beneficial under both deficient and toxic soil zin conditions. Plant Soil. 2013; 371:299-312.

48. Watts-Williams SJ, Smith FA, McLaughlin MJ, Patti AF, Cavagnaro TR. How important is the mycorrhizal pathway for plant Zn uptake? Plant Soil. 2015; 390:157-66.

49. Watts-Williams SJ, Tyerman SD, Cavagnaro TR. The dual benefit of arbuscular mycorrhizal fungi under soil zinc deficiency and toxicity: linking plant physiology and gene expression. Plant Soil. 2017;420:375-88.

50. Welch RM, Graham RD. Breeding for micronutrients in staple food crops from a human nutrition perspective. J Exp Bot. 2004;55:353-64.

51. Wessells KR, Brown KH. Estimating the global prevalence of zinc deficiency: results based on zinc availability in National Food Supplies and the prevalence of stunting. PLoS One. 2012;7:e50568.

52. Zadoks JC, Chang TT, Konzak CF. Decimal code for growth stages of cereals. Weed Res. 1974;14:415-21.

53. Zarcinas BA, Cartwright B, Spouncer LR. Nitric acid digestion and multielement analysis of plant material by inductively coupled plasma spectrometry. Commun Soil Sci Plant Anal. 1987;18:131-46.

54. Zhang S, Lehmann A, Zheng W, You Z, Rillig MC. Arbuscular mycorrhizal fungi increase grain yields: a meta-analysis. New Phytol, in press. 2019. https://doi.org/10.1111/nph.15570.

Ready to submit your research? Choose BMC and benefit from:

- fast, convenient online submission

- thorough peer review by experienced researchers in your field

- rapid publication on acceptance

- support for research data, including large and complex data types

- gold Open Access which fosters wider collaboration and increased citations

- maximum visibility for your research: over $100 \mathrm{M}$ website views per year

At BMC, research is always in progress.

Learn more biomedcentral.com/submissions 